\title{
Modelling the biogeochemical cycles of elements limiting primary production in the English Channel. II. Sensitivity analyses
}

\author{
Thierry Hoch, Alain Ménesguen*
}

Laboratoire de Chimie et Modélisation des Cycles Naturels, Direction de l'Environnement et de l'Aménagement du Littoral Institut Français de Recherche pour l'Exploitation de Ia Mer (IFREMER), Centre de Brest, BP 70, F-29280 Plouzané, France

\begin{abstract}
A general framework for an ecological model of the English Channel was described in the first of this pair of papers. In this study, it was used to investigate the sensitivity of the model to various factors: model structure, parameter values, boundary conditions and forcing variables. These sensitivity analyses show how important quota formulation for phytoplankton growth is, particularly for growth of dinoflagellates. They also stress the major influence of variables and parameters related to nitrogen. The role played by rivers and particularly the river Seine was investigated. Their influence on global English Channel phytoplanktonic production seems to be relatively low, even though nutrient inputs determine the intensity of blooms in the Bay of Seine. The geographical position of the river Seine's estuary makes it important in fluxes through the Straits of Dover. Finally, the multi-annual study highlights the general stability of the English Channel ecosystem. These global considerations are discussed and further improvements to the model are proposed.
\end{abstract}

KEY WORDS: English Channel Sensitivity analyses Ecological model

\section{INTRODUCTION}

In the companion paper, Ménesguen \& Hoch (1997) depicted a 2-element ( $\mathrm{N}$ and $\mathrm{Si}$ ) box-model. They described a physical sub-model combined with biological equations. This physical scheme integrates a horizontal transport box-model and a vertical 2-layer thermohaline model. Simulations clearly highlight the role of stratification in determining primary production in the English Channel.

However, modelling is also a way to study system reactions and sensitivity to fluctuations in parameters and processes, terrestrial inputs and meteorological forcing. For instance, Fransz \& Verhagen (1985) modelled the ecosystem dynamics of the Dutch coast, which is directly influenced by high nutrient river supply. Similarly, Chapelle et al. (1994) investigated eutrophication phenomena in the Bay of Vilaine (South Brittany, France). Radach \& Moll (1993) studied the influence of seasonal stratification and inter-annual meteorological forcing

•E-mall: amenesg@ifremer.fr variations on ecosystem behaviour at a central North Sea station. Jamart et al. (1979) carried out several numerical experiments by varying the parameter values and equations of a previously published model. Moloney \& Field (1991), following Platt et al. (1981), explored 4 areas of model sensitivity: sensitivity to parameters, to initial values, to functional form and to model structure. Fasham (1995) used a model to test 5 hypotheses in order to explain differences encountered in phytoplankton dynamics between North Atlantic and North Pacific stations. His simulations were performed with the help of 2 models: a simple one (phytoplankton-zooplanktonnutrient) and a model which also considered explicit predation by carnivores, 2 compartments for dissolved inorganic nitrogen (nitrate and ammonium) and detrital compartment.

Thus sensitivity analyses are wide-ranging, and can be quite useful for modelling studies in that they represent a simple way of testing models. This paper will illustrate various aspects of sensitivity analysis and detail the results obtained for the English Channel. This sensitivity analysis will particularly emphasize the role of 
terrestrial inputs relative to the influence of meteorological forcing. In an epicontinental sea like the English Channel, the major question concerns the role of nutrient supply from rivers in the ecosystem's dynamics.

\section{THE MODEL AND METHODS OF ANALYSING SENSITIVITY}

\section{The basic model}

We will refer to the model described in Ménesguen \& Hoch (1997). However, a slightly more complex model will be used to investigate the influence of the introduction of a cell-quota formulation for cinoflagellates. Moreover, the biogeochemical cycle of the limiting elements is augmented by taking phosphorus into account.

Hydrodynamic submodel. Long-term circulation: Long-term 2-dimensional circulation is extrapolated from a numerical model elaborated by Salomon \& Breton (1993). This lagrangian model takes into account the coupled effects of tide and average wind on the residual circulation. Using this circulation, the English Channel was divided into 71 boxes, schematizing the main physical and biological features of different parts of the area. The following zones were defined (see Fig. 1 of Ménesguen \& Hoch 1997): (1) coastal zones, under the direct influence of nutrient inputs from rivers, (2) eddy zones, characterized by high residence times, (3) zones where trajectories can be considered as being straight, associated with larger boxes.

The Normand-Breton Gulf and the Bay of Seine are described with more accuracy, in order to better describe the strong gyres and shallow areas in the former zone and the strong Seine plume horizontal gradient in the latter.

Advection and diffusion processes between boxes were considered. Diffusion depends on tidal current velocity and water depth. Fluxes between boxes were automatically calculated by ELISE ecological modelling software (Ménesguen 1991).

Vertical structure: The importance of the seasonal thermocline in the western English Channel and of the halocline in the Bay of Seine has been amply proven (Pingree et al. 1976, Holligan \& Harbour 1977. Ménesguen et al. 1995). To simulate a pycnocline occurrence, we combined horizontal circulation with a vertical thermohaline model. This integral model, first developed by Niiler \& Kraus (1977) and then adapted by Agoumi et al. (1983), divides the water column into 2 layers. The thickness of these layers depends on turbulence induced by either wind or tidal stirring and on the following 'source' and 'sink' terms: heat fluxes at the air-sea interface for the thermal model; freshwater supply from rivers for the haline model. Evaporation and precipitation were not taken into account.

The thermal model reproduces western spring stratification in the English Channel. Surface and bottom temperatures correspond closely to those measured by Pingree (1975), at $\operatorname{Stn} \mathrm{E}_{1}$. Haline stratification is seen in the Seine plume. The thermohaline model provides exchange velocities between the 2 vertical layers in each box, which are then applied to any ecological variable, other than benthic.

Biological sub-model. Conceptual scheme: The global features of the biological sub-model were inspired by the model described by Ménesguen \& Hoch (1997). To investigate competition between diatoms and dinoflagellates, 2 elements, nitrogen and silicon, were considered in the previous model and phosphorus was included in this study. Phosphorus, like nitrogen and silicon, appears to be one of the limiting elements of primary production in coastal waters. It has long been identified as the main limiting element in limnetic environments. In marine systems, its role is open to debate, but cannot be ignored. Radach \& Moll (1993), for instance, used phosphorus as the only element in their model which they applied to the North Sea. Including nitrogen, phosphorus and silicon in a single model allows the limiting elements in each area of the English Channel to be identified. It also appears that phosphorus should be taken into account when studying the influence of terrestrial inputs.

The model considers these elements under the following forms: total dissolved inorganic; phytoplankton, divided into diatoms and dinoflagellates; detrital in water; organic in benthos.

Dividing the phytoplankton into diatoms and dinoflagellates gives realistic representation of most situations encountered. A constant N:P:Si ratio was used for diatoms. Nutrient limitation by one of these elements was considered using a Michaelis-Menten formulation. According to Liebig's law, the final limitation results from the minimum of all limitations, including that of light:

$\mu_{\text {diat }}=\mu_{\text {maxdiat }} \cdot f_{\mathrm{T}} \cdot \min \left(f_{\text {Ldiat }}, f_{\text {Nutdiat }}\right):$ diatom growth rate

$f_{\text {Nutdiat }}=\min \left(f_{\text {Ndiat }}, f_{\mathrm{S}}, f_{\text {Pdiat }}\right) \quad$. nutrient limitation

with $f_{\text {Nutdiat }}=\frac{[\mathrm{Nut}]}{k_{\text {Nutdiat }}+[\mathrm{Nut}]}$

where $f_{\text {Ldiat }}$ is action of light limitation on diatoms (see Ménesguen \& Hoch 1997), $f_{\mathrm{T}}$ is action of temperature (see Ménesguen \& Hoch 1997), $\mu_{\max }$ is the maximum growth rate, $f_{\text {Nuldiat }}$ is limitation function of diatom growth by nutrients, [Nut] is concentration of nutrients in sea water ( $N, P$, or $\mathrm{Si}$ ), $k_{\text {Nutdiat }}$ is half-saturation constant for uptake of nutrients.

Because of relatively slow dinoflagellate growth and the possibly long period between uptake and organic 
incorporation of nutrients, a cell-quota model was tested for these algae. Tett et al. (1986) and Sharples \& Tett (1994) have already described phytoplankton growth within a sharp pycnocline using such a model. This formulation was also applied to Dinophysis blooms in the Bay of Vilaine (Ménesguen et al. 1990). It results in uptake and growth being separated, thus requires additional variables to represent the internal nutrient storage compartments of nitrogen and phosphorus. Indeed, growth dynamics are much faster for siliceous algae and the delay between uptake and growth can be considered short enough for diatoms to be ignored, with respect to seasonal dynamics.

Droop (1973) depicted growth of dinoflagellates with the help of a cell-quota model, using the following formulation for the growth rate:

$$
\mu=\mu_{\max } \frac{\left(q-q_{\min }\right)}{k_{\mathrm{q}}+\left(q-q_{\min }\right)}
$$

where $q$ is the internal nutrient content of each cell (quota), $q_{\min }$ is the minimal quota, under which growth rate is set to zero, $k_{\mathrm{q}}$ is the half-saturation constant for growth

Experimentally, it has been observed that:

$$
k_{\mathrm{q}} \approx q_{\mathrm{min}}
$$

Eq. (4) then becomes (Goldman \& Glibert 1983):

$$
\mu=\mu_{\max }\left(1-\frac{q_{\min }}{q}\right)
$$

Internal nitrogen content thus determines the nutrient limitation of dinoflagellate growth.

The uptake rate $(V)$ is considered separately and mainly depends on surrounding nutrient concentrations, as per Michaelis-Menten:

$$
V=V_{\max } \frac{[\text { Nut }]}{k_{\text {Nut }}+[\text { Nut }]}
$$

where $V_{\max }$ is the maximal uptake rate, $k_{\mathrm{Nut}}$ is the halfsaturation constant for uptake.

Nevertheless, uptake does not occur whenever the nitrogen quota reaches or exceeds a maximal threshold $q_{\max }$.

Equations are identical for nitrogen and phosphorus, thus enabling a continuous study of the internal N:P ratio.

Zooplankton were not taken into account, but differential grazing pressure on diatoms and dinoflagellates (Huntley 1982) is expressed through a higher mortality rate for siliceous algae.

Non-living organic matter was defined in the water column and in the benthos. The benthic compartment is subject to resuspension, correlated to tidal currents, and to remineralization, for nitrogen and phosphorus. These schematized benthic processes ensure that the system is closed, and the renewal of inorganic nutrients during the winter.

Diatoms, dinoflagellates and total phytoplanktonic production were calculated based on the equations described in Ménesguen \& Hoch (1997). Equations and parameters derived the new model, considered as the reference model in this study, are listed in Appendix 1.

In boundary conditions, inorganic phosphate concentrations were considered in both the Atlantic Ocean and rivers, as were inorganic nitrogen and silicon inputs in the first paper Forcing variables were already described there.

Inorganic phosphorus measurements were taken from the same calibration data set used in the companion paper.

\section{Different techniques for sensitivity}

As previously mentioned, sensitivity may vary in nature. We can distinguish and define 'internal' sensitivity, involving the model's structure, variables, equations and parameters, and 'external' sensitivity, concerning boundary conditions and forcing variables.

Sensitivity to model structure. Influence of including phosphorus: The influence of taking phosphorus into account was investigated by comparing differences in chlorophyll a (chl a) simulations between models with and without phosphorus. An indirect way of studying the influence of phosphorus is to examine nutrient limitation of phytoplankton growth. To investigate nutrient limitation of phytoplankton growth, we compared diatom limitation functions $f_{\mathrm{Nut}}$ described by Eq. (3), for nitrogen, silicon and phosphorus. To account for the limitation of dinoflagellate development, we calculated the internal N:P ratio. The lower this ratio is, the more limiting $N$ is for phytoplankton growth. This is reciprocal for $P$.

Influence of the cell-quota formulation for dinoflagellates: This influence was investigated by comparing the results from the present model to those of the same without quota, similarly to Haney \& Jackson's work (1996). In this case, the time variations of nitrogen in dinoflagellates are described by the following equation:

$$
\begin{aligned}
& \frac{\mathrm{dDinoN}}{\mathrm{d} t}= \\
& \left(\mu_{\text {maxdino }} f_{\mathrm{T}} \min \left(f_{\text {Ndino }}, f_{\text {Pdino }}, f_{\text {Ldino }}\right)-m_{\text {dino }} f_{\mathrm{T}}\right) \cdot \operatorname{DinoN} \\
& f_{\text {Nutdino }}=\frac{[\mathrm{Nut}]}{k_{\text {Nutdino }}+[\text { Nut }]}
\end{aligned}
$$

where Dino $\mathrm{N}$ is nitrogen in dinoflagellates $\left(\mathrm{mol} \mathrm{l}^{-1} \mathrm{~N}\right)$, and Nut represents inorganic $N$ or $P$ here.

Phosphorus content is considered using a Redfield ratio $\left(\mathrm{P}: \mathrm{N}=1: 16 \mathrm{~mol} \mathrm{P}\right.$ mol $\left.\mathrm{N}^{-1}\right)$. 
Moreover, for the reference model the dependence of the extinction coefficient $\left(k_{2}\right)$ on dinoflagellate abundance was used:

$k_{Z}=k_{\mathrm{NC}}+k_{1} \cdot(\operatorname{DiatN})^{2 / 3}+k_{2} \cdot \operatorname{DiatN}+k_{3} \cdot$ DinoCell

where DiatN is nitrogen in diatoms $\left(\mu \mathrm{mol} l^{-1} \mathrm{~N}\right)$, DinoCell is dinoflagellate abundance (cell $l^{-1}$ ), $k_{\mathrm{NC}}$ is the non-chlorophyllous extinction coefficient, $k_{1}$ and $k_{2}$ are coefficients in Riley's formulation, $k_{3}$ is the influence of dinoflagellate concentration on extinction coefficient.

In order to make a strict comparison between models with or without quotas, we simulated the extinction coefficient, using a Riley formulation (Riley 1975) in both cases. Thus, it follows that:

$k_{2}=k_{\mathrm{NC}}+k_{1} \cdot(\operatorname{DiatN}+\operatorname{DinoN})^{2 / 3}+k_{2} \cdot(\operatorname{DiatN}+\operatorname{DinoN})$

We focused on boxes $B$ and $D$, because ecosystem dynamics differ drastically from one box to the other. The former is situated in a frontal zone of the western English Channel, whereas the latter is under the direct influence of the river Seine nutrient supply

Sensitivity of the physical environment to biological processes: Physical phenomena may be influenced by biological activity, especially when they depend on optical properties of sea water, because the chlorophyllous part of the extinction coefficient is related to diatom and dinoflagellate concentrations, as shown by Eq. (10).

To investigate the influence of phytoplankton concentrations on spring thermal stratification, we removed the phytoplankton-dependent terms from the extinction coefficient formulation for the thermal model. Simulation results were compared between this model and the reference model for box $\mathrm{B}$, whose ecosystem is particularly affected by stratification.

Sensitivity to parameters of the biological model: Sensitivity analysis on parameters is among the most commonly performed tasks in ecological modelling. Parameters involved are listed in Appendix 1. To investigate the sensitivity of these 29 parameters, 250 Monte Carlo simulations were carried out, as per Tiwari \& Hobbie (1976). Before each simulation, parameters were randomly selected for a normal distribution, with an average equal to the reference value and the standard deviation equivalent to $10 \%$ of this value. These Monte Carlo simulations can be summarized for each variable at any time by means of an average value and a standard deviation, but they also provide information between some variables (e.g. a global one such as the total yearly primary production on the English Channel) and the various parameters.

Thus a backward stepwise regression analysis was performed between these 250 total productions and the corresponding sets of parameters. F-statistics were calculated for each parameter, evaluating the level of variance it explains. Step by step, parameters whose
$F$-value was lower than 6 were removed and new $F$ statistics were computed until all remaining variables showed an $F$-value above this threshold. This identified the parameters to which the model is the most sensitive.

Spatial distribution of sensitivity to parameters was approached using a standardized index calculated for each box of the English Channel. This index is based on the diatom nitrogen concentration and in each box, is equal to the maximal standard deviation between the 250 runs, divided by the bloom peak value, during the spring period.

Sensitivity to external factors. Sensitivity to boundary conditions: We investigated the influence of inputs from rivers as well as from the Atlantic Ocean. This influence was highlighted through the use of global indexes: yearly diatom, dinoflagellate and total phytoplanktonic primary production, yearly fluxes of total $N$, $P$ and Si crossing the Straits of Dover, yearly average phytoplanktonic nitrogen concentrations for the whole English Channel.

Several scenarios, featuring different inputs, were performed. The role of rivers was studied by removing terrestrial inputs. The specific role of the river Seine was investigated through simulations with or without this river alone. Scenarios considering anthropogenic input variations were carried out by multiplying or dividing $N$ and P supply by 2 and taking both of these elements together or separately. To determine the effect of the Atlantic oceanic boundary supply, inputs of nutrients, diatoms or dinoflagellates were also multiplied or divided by 2 .

Sensitivity to meteorological forcing: The sensitivity of the model to meteorological forcing was studied by simulating the 15 yr from 1978 until 1992. Real daily meteorological data collected at La Hague (Normandy, France) were used, as well as the main flow rates and nutrient concentrations inputs by the river Seine. Comparison among all these years was performed using global indexes, such as annual primary production, total fluxes of N, P and Si through the Straits of Dover, average phytoplanktonic concentrations, yearly heat balance and nutrient supply from the river Seine. This study allowed exceptional years to be identified and these simulated years will be more particularly detailed.

\section{RESULTS}

Simulation of ecosystem dynamics for the year 1980

Inorganic phosphorus simulation

Simulated inorganic phosphorus concentrations were plotted for the 5 boxes in Fig. 1. High winter inorganic 


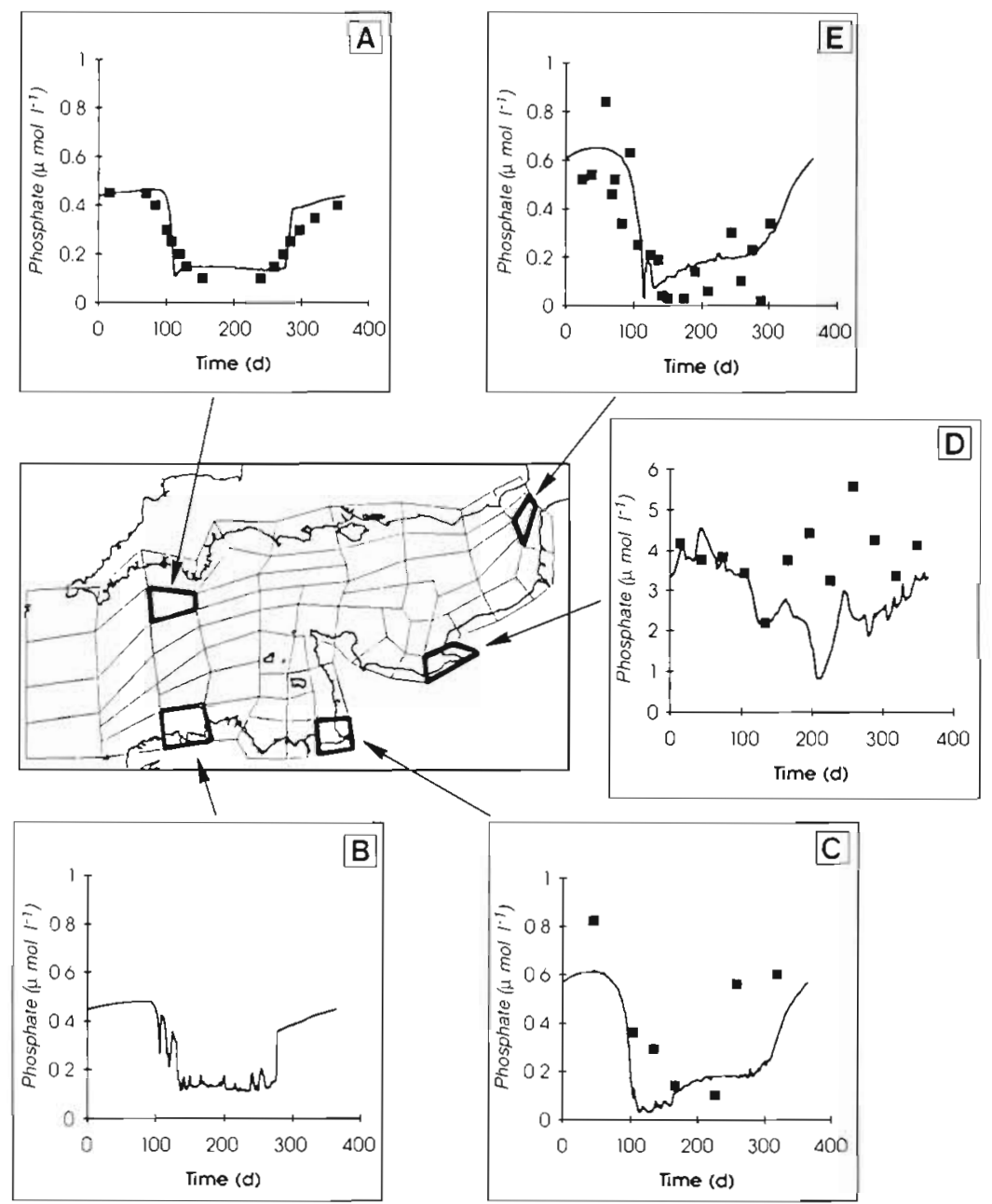

Fig. 1 Simulation of surface inorganic phosphorus cycle and comparison with literature data ( (in $\mu \mathrm{mol} \mathrm{l^{-1 }}$ P), for 5 boxes used for model evaluation. (A) Central western English Channel, off Plymouth; (B) coastal frontal zone in the western Channel; (C) shallow coastal area of the Normand-Breton Gulf; (D) box off the Seine estuary; (E) central zone of the Straits of Dover

in coastal zones (boxes $C$ and D), particularly during summer and autumn. The latter are mainly due to a lack of organic phosphorus inputs or process formulation, such as phosphate desorption from sediment and suspended matter. The processes concerning phosphorus are highly complex, and are not dealt with for the time being.

\section{Chlorophyll a simulation}

To synthesize results from the reference model, simulated chl a curves were plotted for the most representative boxes of the English Channel (Fig. 2). As in the companion paper, phytoplanktonic nitrogen concentration ( $\mu \mathrm{mol} \mathrm{l}^{-1} \mathrm{~N}$ ) was considered as equivalent to chlorophyll a concentration ( $\mathrm{gg}$ $\mathrm{l}^{-1} \mathrm{chl}$ a)

Spring phytoplankton blooms are mainly related to 2 phenomena: winter inorganic nutrients and thickness of the mixed layer. In the western English Channel, the occurrence of the spring bloom depends on the appearance of stratification. This explains the earliness of the bloom in the northern area compared with the southern one. At Stn $E_{1}$ (box $A$ ), the model reproduces the major features of the ecosystem's dynamics, and particularly chl a concentrations, under temporary stratified conditions, described by Holligan \& Harbour (1977). Yet, summer concentrations appear to be excessive. Dis-

phosphorus concentrations were simulated in the Bay of Seine (box D), mainly attributed to human activities in the catchment area. Elsewhere, concentrations were much lower, even in a coastal zone of the NormandBreton Gulf (box C). Following phytoplanktonic development, a general decrease of these concentrations was observed in spring. Yet, phosphorus depletion was not seen anywhere in the water column, except during transient spring periods in the Normand-Breton Gulf and the Straits of Dover (box E), after which a high remineralization rate prevented longer phosphorus limitation. Restoration of the winter nutrient stock was achieved in autumn.

Comparisons of data correlated well for the Straits of Dover. In the western English Channel (box A), results also corresponded to descriptions by Pingree et al. (1977). In contrast, discrepancies were encountered crepancies encountered in summer may be driven by over-abundant nutrient fluxes from the bottom through the pycnocline.

Off northern Brittany (box B), stratification is not as well established as further north and the surface layer is thinner. Instability of the thermocline generates a succession of small phytoplankton blooms.

Haline stratification in the Bay of Seine (box D) is also responsible for early phytoplankton growth, although turbidity in this area is among the highest encountered in the English Channel.

On the other hand, the intensity of episodic phytoplankton blooms seems to depend mainly on inorganic nutrient concentrations. This explains the great differences between chl a concentrations in the NormandBreton Gulf and the Bay of Seine. Furthermore, in the latter area, continuous nutrient supply promotes 


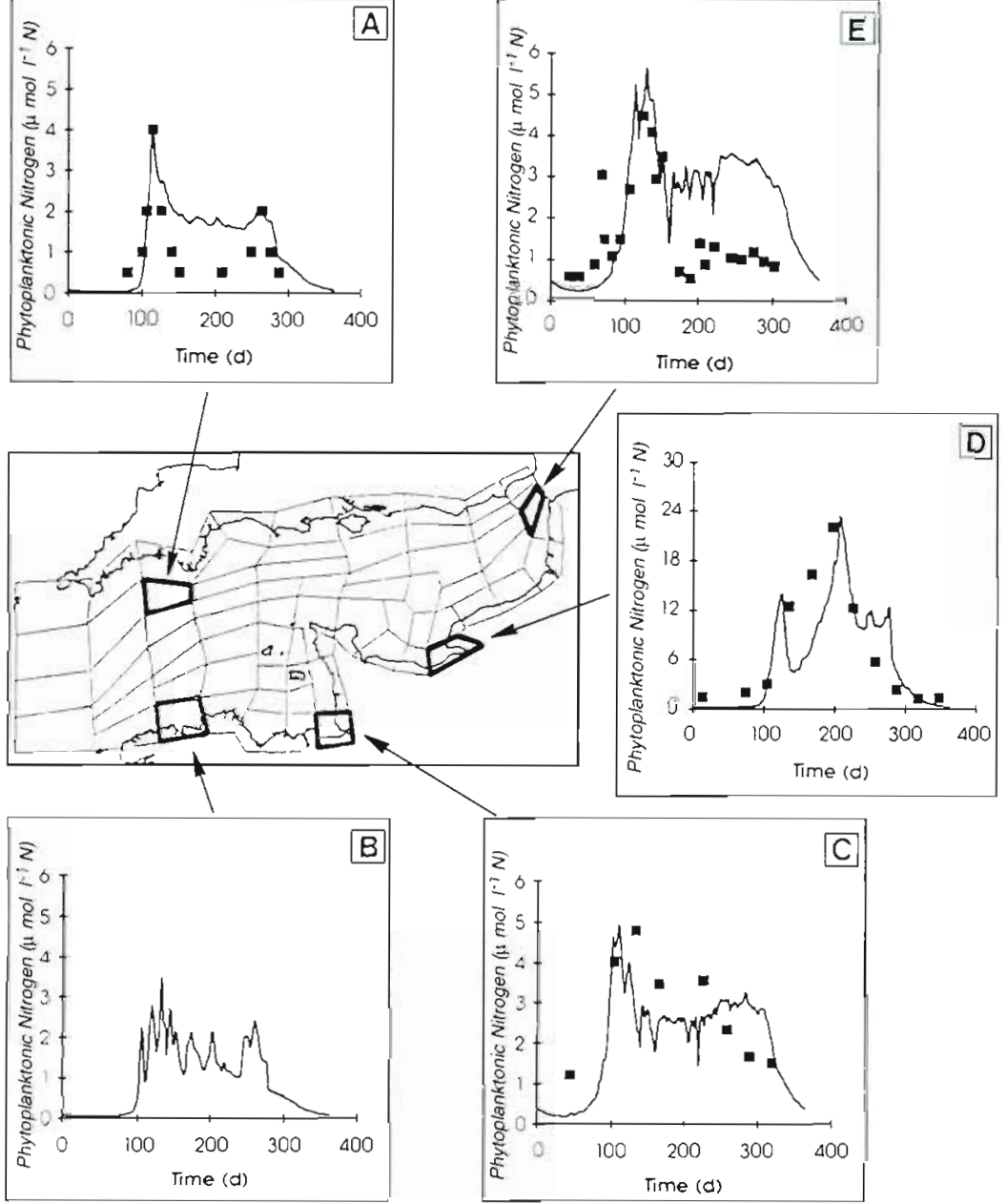

Fig. 2. Simulation of surface phytoplanktonic nitrogen cycle and comparison with literature data ( $\left(\right.$ in $\mu \mathrm{mol} \mathrm{l}^{-1} \mathrm{~N}$ )
Fluxes through the Straits of Dover

Modelling the biogeochemical cycle of N,P and Si in the English Channel allows yearly nutrient fluxes through the Straits of Dover to be calculated. Fluxes calculated by the model approach those estimated by Bentley et al. (1993), with the help of monthly measurements between September 1990 and September 1991 (Table 1). Results from the model could greatly be improved by taking into account seasonal water flux variations through the Straits of Dover.

\section{Sensitivity analyses}

Influence of the structure of the model

Influence of including phosphorus: In fact, the consideration of phosphorus brought about only slight differences when compared to the previous model. Fig. 3 shows the chl a concentrations in the Normand-Breton Gulf (box C). In this area, the model exhibits a decrease in the spring phytoplankton bloom with respect to the former model because of limitation by inorganic phosphorus.

The low influence of phosphorus is illustrated by Fig. 4, where the Michaelis-Menten limitation functions of diatom growth are plotted for boxes summer phytoplankton growth, thus enabling the development of a bloom in July.

Whereas the spring bloom is relatively well represented in the Normand-Breton Gulf and the Straits of Dover, post-bloom chlorophyll concentrations are overestimated by the model. This could be due to the lack of explicit zooplankton grazing formulation in our model. Otherwise, chl a simulations roughly follow most situations encountered.

Table 1. Comparison of measured and simulated inorganic

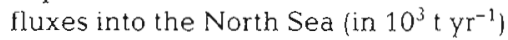

\begin{tabular}{|lccc|}
\hline & Nitrogen & Silicon & Phosphorus \\
\hline Bentley et al. (1993) & 209 & 270 & 41 \\
Present study & 218 & 266 & 43 \\
\hline
\end{tabular}

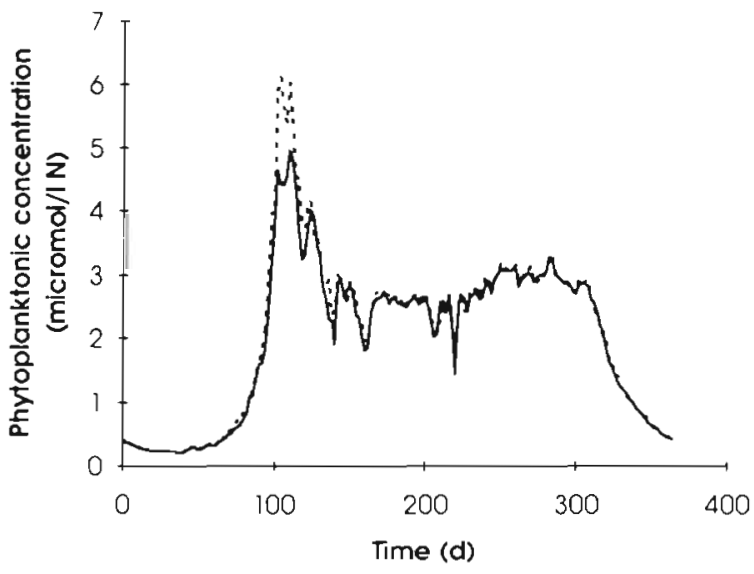

Fig. 3. Comparison of phytoplanktonic nitrogen concentrations in the Normand-Breton Gulf simulating (solid line: present model) or not simulating (dotted line: reference model) phosphorus cycle (in $\mu \mathrm{mol} 1^{-1} \mathrm{~N}$ ) 

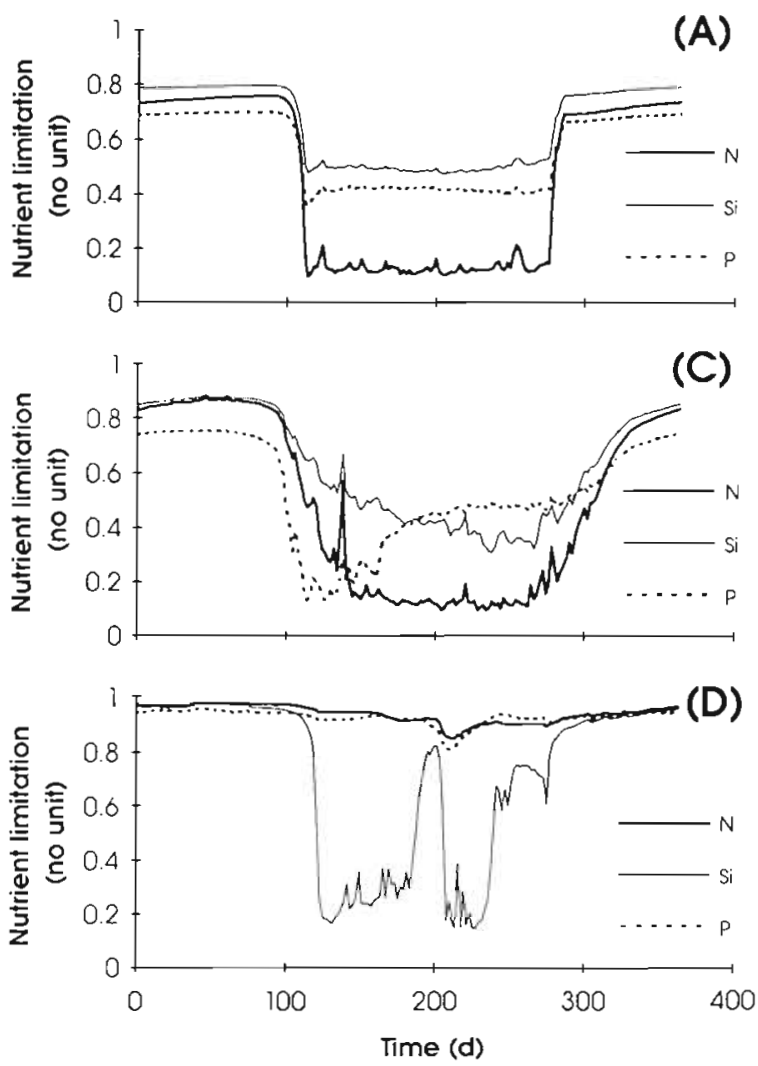

Fig. 4. Time course of $\mathrm{N}-, \mathrm{Si}$ - and P-limitation factors for diatoms in boxes $\mathrm{A}, \mathrm{C}$ and $\mathrm{D}$

A, C and D. For the western English Channel (box A), and more generally for non-coastal areas, our model exhibits major limitation by nitrogen, during the period when light no longer limits growth, essentially in spring and summer. However, other elements may appear to temporarily or continuously limit diatom growth in coastal zones. This is the case for phosphorus in the Normand-Breton Gulf (box C), over a short period. The fact that the limiting effect of $P$ on phytoplankton growth is only transient is due to its high rem-

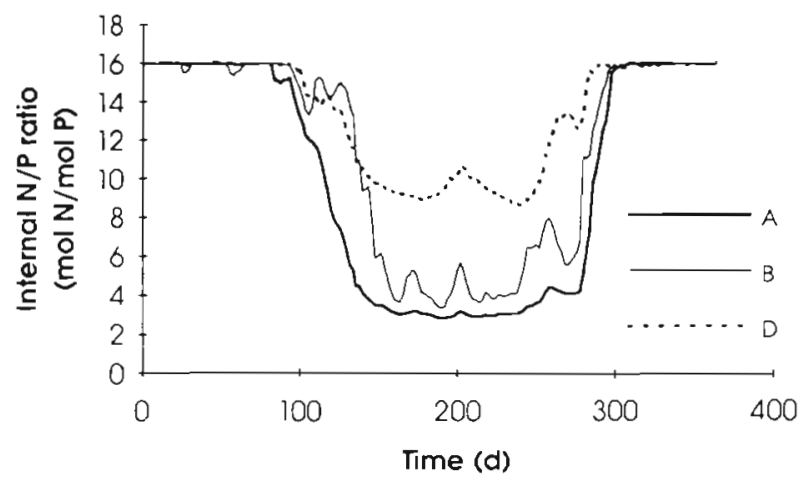

Fig. 5. Evolution of N/P internal ratio in dinoflagellate cells for boxes $\mathrm{A}, \mathrm{B}$ and $\mathrm{D}$ ineralization rate. In the Bay of Seine (box D), diatoms are always limited by silicon during the period of phytoplanktonic production. Nevertheless, all nitrogen forms were taken into account for supply from the river Seine, whereas only phosphate and dissolved silica were considered elsewhere. This could lead to a deficit in dissolved $\mathrm{P}$ and Si concentrations.

In coastal areas, $N, P$ and $S i$ thus potentially limit phytoplankton development during the productive period. However, results are mainly dependent on remineralization and dissolution rates, which may greatly vary both seasonally and spatially, and on the choice of a constant N:P:Si ratio for diatoms.

The major role played by nitrogen is illustrated by Fig. 5, where the N:P ratio of dinoflagellate internal storage compartment is plotted for boxes $\mathrm{A}, \mathrm{B}$ and $\mathrm{D}$. In every case, the ratio decreases during the period of production, indicating that nitrogen limitation prevails over that of phosphorus. Thus modelling internal compartments provides a continuous study of phytoplankton cell composition and limitation.

Influence of the cell-quota formulation for dinoflagellates: Fig. 6 shows concentration of $\mathrm{N}$ in dinoflagellates in the western English Channel (box B) and the Bay of Seine (box D) in 3 cases: when a cell-quota model, with 2 different formulations of the extinction coefficient, was applied to $N$ and $P$, and when no internal compartment was considered.

Taking an internal compartment into account tends to favour dinoflagellate growth in stratified, nutrientpoor areas of the western English Channel, as a result
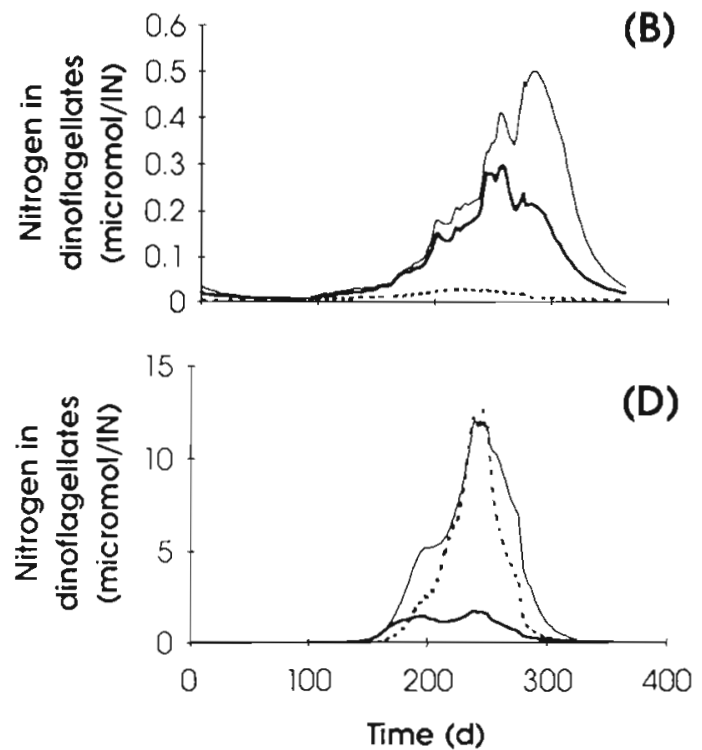

Fig. 6. Time course of simulated dinoflagellate concentrations in boxes $B$ and $D$ without any quota (dotted line), and with $a$ quota model, considering (thin line) or not considering (thick line) a Riley function for the self-shading process 


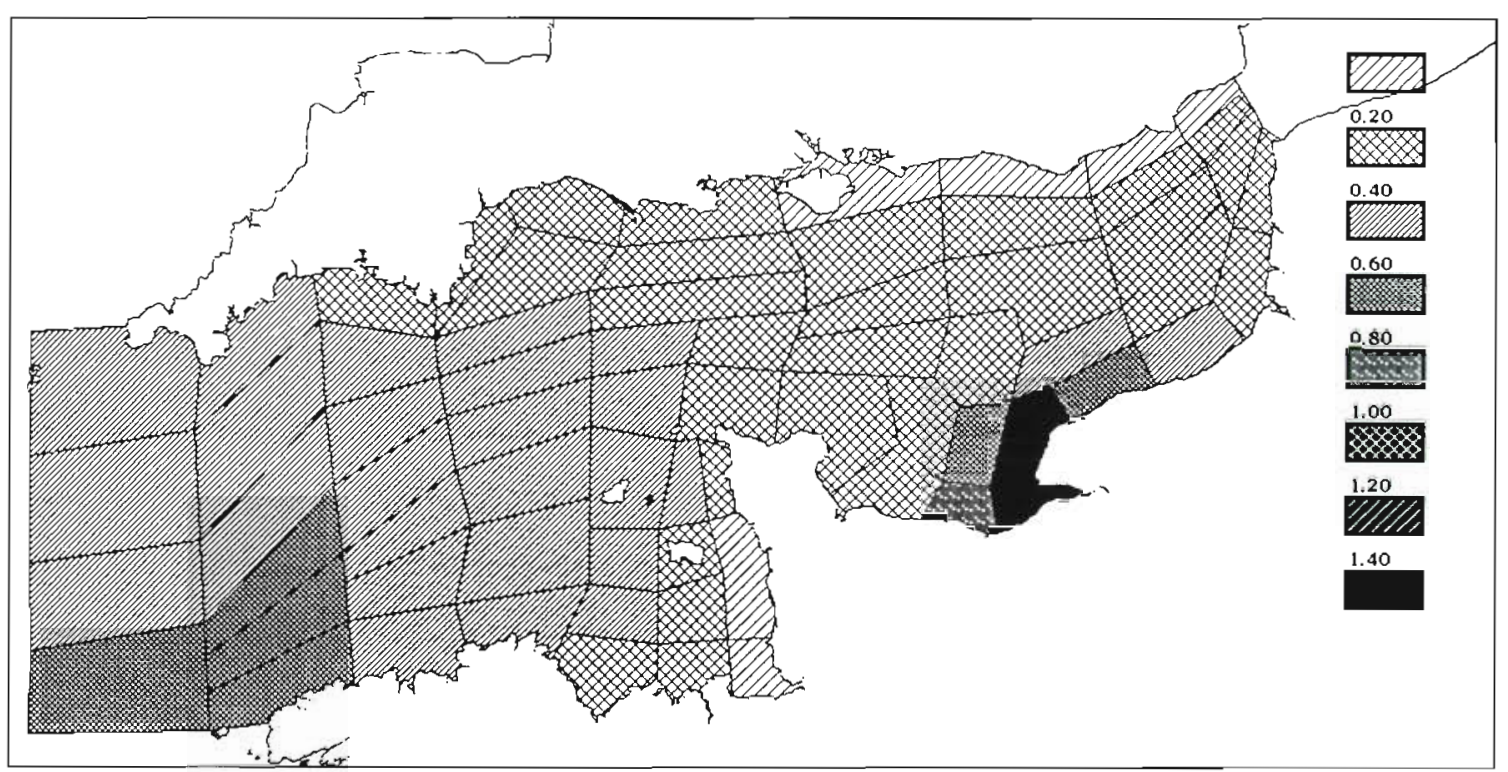

Fig. 7. Map of the simulated annual dinoflagellate production (in $\mathrm{g} \mathrm{N} \mathrm{m}^{-2} \mathrm{yr}^{-1}$ )

of nutrient stocks accumulated in phytoplankton cells. Several authors have reported the development of dinoflagellates in frontal and stratified systems of the English Channel (Holligan \& Harbour 1977. Holligan et al. 1984, Le Corre et al. 1993). In the nutrient-rich waters of the Bay of Seine, dinoflagellate development mainly depends on the self-shading process considered, although quotas still lead to slightly higher growth, when using a Riley function. Higher values for the extinction coefficient, and consequently slower phytoplankton growth, are obtained with a formulation which depends on dinoflagellate abundance. In the
Bay of Seine, the simulation most realistically follows chl a measurements when the latter formulation is used. In contrast, Riley's original formula leads to overestimated autumn concentrations, along with excessive relative abundance of dinoflagellates, since they were not shown to represent more than $10 \%$ of the total algal biomass in 1992 (M. Ryckaert pers. comm.).

Yearly integrated dinoflagellate production, which is shown in Fig. 7, exhibits much lower production levels than that of diatoms (see Fig. 9 in Ménesguen \& Hoch 1997). Production is spatially restricted to thermally stratified areas of the western English Channel on the
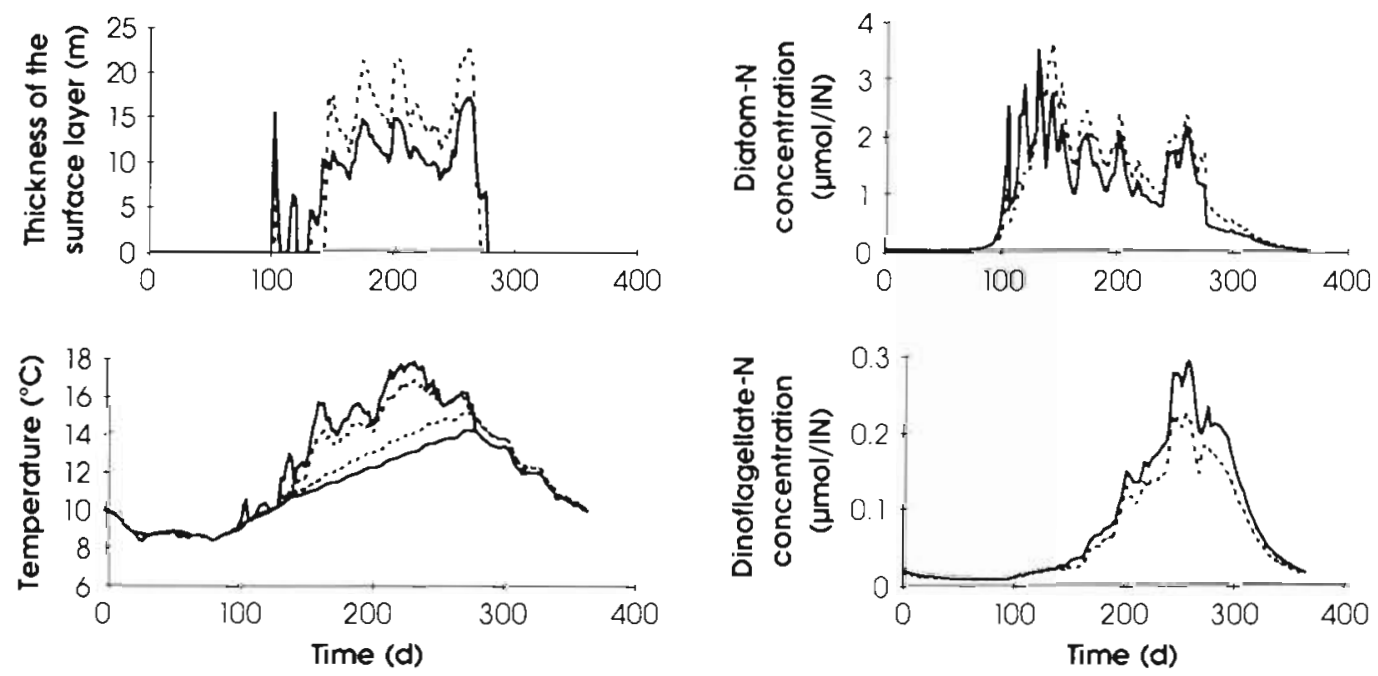

Fig. 8. Simulation of different variables in box B with a model considering (solid line; reference model) or not considerng (dotted linel phytoplankton influence on light extinction. Temperature traces concern respectively surface (upper lines) and bottom (lower lines) layers 
one hand and to stratified enriched waters of the Bay of Seine on the other.

Sensitivity of the physical environment to biological variables: Marked differences with the reference model are shown in Fig. 8, where results for northern Brittany (box B) are plotted. A reduced extinction coefficient generates a delay in establishment of the thermocline. This pycnocline is deeper, but more numerous exchanges between the surface and the bottom layers result in a lower temperature difference between them. These major physical modifications initially lead to a later phytoplankton bloom. The weaker summer stratification then favours diatom growth compared to that of dinoflagellates. These results provide truly individualized feed-back for biological dynamics on thermal processes

Sensitivity analysis to parameter values: Table 2 gives sensitivity parameters with their regression coefficient. Results clearly highlight the influence of irradiance through parameters $I_{\text {saldial }} I_{\text {saldino }}$ and of the penetration of light with self-shading parameters $k_{1}$ and $k_{3}$. Parameters related to nitrogen have the greatest influence, as shown by the sensitivity of the model to $r_{\operatorname{minN}}, k_{N_{\text {dial }}}$ and the stoichiometric ratio with silicon $\left(r_{\mathrm{Si} / \mathrm{N}}\right)$. No parameter for phosphorus reached the $F$-test significance level. Additionally, first order parameters related to growth and mortality of diatoms as well as dinoflagellates also played a major role. The temperature-dependence parameter $k_{\mathrm{T}}$, acting directly on growth, mortality and remineralization was logically selected. Analysis of the regression coefficients provides an interesting point, i.e. those applied to dinoflagellates always tend towards a decrease in total
Table 2. Regression coefficients of stepwise variable selection between total productions and parameter values in Monte Carlo sensitivity analysis

\begin{tabular}{|lc|}
\hline ParameteI & Regression coefficient $\left(\times 10^{4}\right)$ \\
\hline$r_{\text {minN }}$ & 2445.6 \\
$k_{\mathrm{T}}$ & 3335.9 \\
$\mu_{\text {maxdiat }}$ & 358.4 \\
$k_{\text {Ndiat }}$ & -21.9 \\
$I_{\text {Satdiat }}$ & -1.5 \\
$r_{\mathrm{S} / \mathrm{N}}$ & -88.4 \\
$m_{\text {diat }}$ & -3287 \\
$\mu_{\text {maxdino }}$ & -398.6 \\
$I_{\text {Satdino }}$ & 0.5 \\
$m_{\text {dino }}$ & 6205.4 \\
$k_{1}$ & -821.4 \\
$k_{3}$ & $3.6 \times 10^{\bar{\gamma}}$ \\
\hline
\end{tabular}

production. This can be regarded as a consequence of competition phenomena. Increased dinoflagellate growth inhibits global phytoplanktonic production, since it slows down development of diatoms, whose growth rate is highest.

Using the sensitivity index, a map featuring the spatial pattern of sensitivity (Fig. 9) was created. This map shows up the model's increased sensitivity to parameters in 2 major areas: the coastal zones, where biological productivity fluctuates considerably and depends on terrestrial inputs, and the frontal zone in the western English Channel, where instability leads to higher sensitivity. The model is also very sensitive in the box receiving supply from the Atlantic Ocean. Otherwise, the sensitivity index appears to be rather

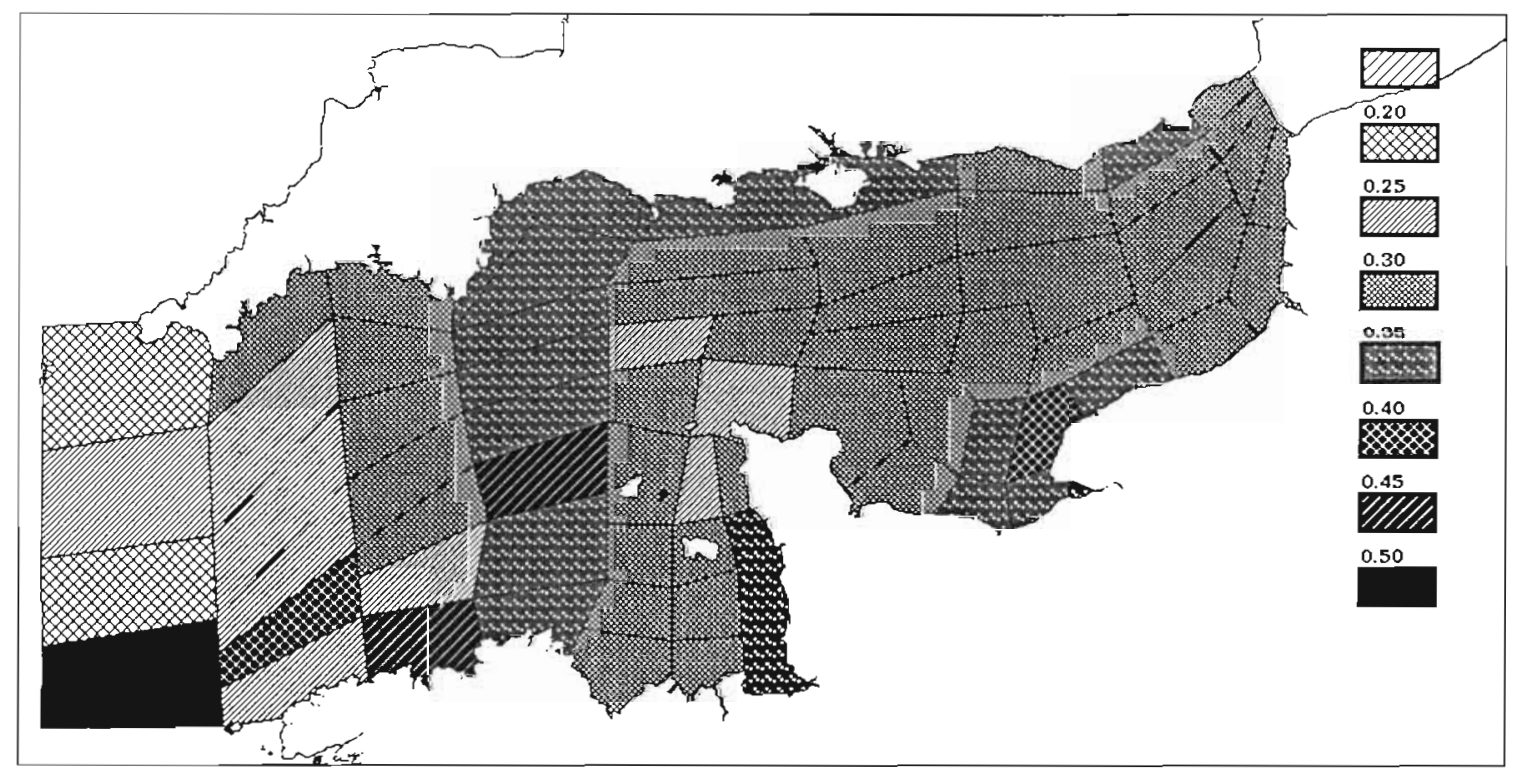

Fig. 9. Map of the sensitivity index to parameters 
weak in stable areas which are either well stratified in spring or totally mixed. Sensitivity to parameters is thus directly and positively correlated to physical instability and external inputs.

\section{Sensitivity analysis to external factors}

Influence of boundary conditions: Different scenarios for inputs from rivers and the Atlantic Ocean respectively led to the calculation of global indexes (primary production, fluxes of elements through the Straits of Dover and average phytoplanktonic concentration), listed in Table 3.

The global influence of rivers on total production appears rather low (about 15\%) but should not be neglected. The table also shows the major role played by the river Seine in primary production. Its influence can be evaluated as equal to that of all the other rivers discharging into the English Channel. Moreover, the river Seine appears as the only river favouring dinoflagellate development, as a result of the haline stratification it generates.

The study of fluxes through the Straits of Dover highlights a more important role of rivers. Indeed, $30 \%$ of total N, $19 \%$ of Si and $17 \%$ of P fluxes could be attributed to the terrestrial inputs. This increased importance, which is particularly true for the nitrogen components, is mainly due to the fact that the main rivers, including the river Seine, discharge into the eastern part of the English Channel. The essential influence of the river Seine is accentuated, especially for $P$, since the river accounts for almost all riverine $P$ inputs to the North Sea.

We also simulated different scenarios concerning nutrient river supply in order to detect eventual anthropogenic changes due to the inputs of inorganic $N$ and P. Dividing or multiplying inorganic nitrogen and phosphorus inputs by a factor of 2 generates a quasisymmetrical reaction from the model with respect to global production. Nevertheless, the distribution of production between diatoms and dinoflagellates shows that increased $\mathrm{N}$ and $\mathrm{P}$ supply favours the development of the latter, as a result of diatom limitation by silicon. This limitation also enhances, although nonsymmetrically for $N$ and $P$, the fluxes through the Straits of Dover. Moreover, changes in N supply lead to similar situations such as modifications in $N$ and $P$ inputs, whereas effects of $\mathrm{P}$ variations appear to be very slight, at least on global production. Therefore, nitrogen inputs can be considered to exert stronger control than phosphorus on global primary production.

The study also allowed the Atlantic Ocean's influence to be investigated by performing the same numerical experiments as for the rivers. Results clearly highlight the major role played by the western boundaries, particularly for nutrient inputs. Modifications were less spectacular for diatoms. For dinoflagellates the effects seem detrimental, since a doubling in supply generates a decrease in global production. As mentioned above, this results from competition phenomena among phytoplanktonic species.

Table 3. Phytoplankton production, fluxes of elements through the Straits of Dover, average phytoplankton concentrations during various numerical experiments on boundary conditions, calculated by percent difference with reference model

\begin{tabular}{|c|c|c|c|c|c|c|c|}
\hline & $\begin{array}{l}\text { Diatom } \\
\text { production }\end{array}$ & $\begin{array}{c}\text { Dinoflagellate } \\
\text { production }\end{array}$ & $\begin{array}{c}\text { Total } \\
\text { production }\end{array}$ & $N$ fluxes & Si fluxes & P fluxes & $\begin{array}{l}\text { Phytoplankton } \\
\text { concentration }\end{array}$ \\
\hline Reference model results: & $\begin{array}{c}271.3 \\
\left(10^{4} \mathrm{t} \mathrm{yr}^{-1}\right)\end{array}$ & $\begin{array}{c}4.3 \\
\left(10^{4} \mathrm{tyr}^{-1}\right)\end{array}$ & $\begin{array}{c}275.6 \\
\left(10^{4} \mathrm{t} \mathrm{yr}^{-1}\right)\end{array}$ & $\begin{array}{c}430 \\
\left(10^{3} \mathrm{tyr}^{-1}\right)\end{array}$ & $\begin{array}{c}477 \\
\left(10^{3} \mathrm{tyr}^{-1}\right)\end{array}$ & $\begin{array}{c}64 \\
\left(10^{3}{\mathrm{t} y \mathrm{r}^{-1}}^{-1}\right)\end{array}$ & $\begin{array}{c}1.17 \\
\left(\mu \mathrm{mol} \mathrm{l} \mathrm{l}^{-1} \mathrm{~N}\right)\end{array}$ \\
\hline \multicolumn{8}{|l|}{ Model differences } \\
\hline \multicolumn{8}{|l|}{ Effects of rivers } \\
\hline Without rivers & -14.5 & -16.3 & -14.5 & -29.8 & -19.3 & -17.2 & -11.9 \\
\hline Without river Seine & -7 & -16.3 & -7.1 & -18.8 & -8.8 & -15.6 & -6 \\
\hline With river Seine only & -7.1 & -2.3 & -7 & -10.2 & -10.1 & 0 & -5.6 \\
\hline $\mathrm{N}$ and $\mathrm{P}$ fluxes multiplied by 2 & +6.2 & +23.3 & +6.5 & +27.9 & +0.2 & +20.3 & +6.8 \\
\hline$N$ and $P$ fluxes divided by 2 & -6 & -11.6 & -6.1 & -13.3 & 0 & -7.2 & -5 \\
\hline $\mathrm{N}$ fluxes multiplied by 2 & +5.7 & +23.3 & +6 & +27.9 & 0 & +1.6 & +5.8 \\
\hline $\mathrm{N}$ fluxes divided by 2 & -5.6 & -11.6 & -5.7 & -13.3 & 0 & +1.6 & -4.4 \\
\hline P fluxes multiplied by 2 & +0.4 & -2.3 & +0.4 & +0.5 & 0 & +20.3 & +0.3 \\
\hline P fluxes divided by 2 & -0.3 & 0 & -0.3 & +0.2 & 0 & -7.3 & -0.2 \\
\hline \multicolumn{8}{|l|}{ Effect of Atlantic Ocean } \\
\hline Fluxes of nutrients multiplied by 2 & +57.5 & +4.7 & +56.7 & +63.3 & +74.6 & +78.1 & +71.5 \\
\hline Fluxes of nutrients divided by 2 & -32.7 & -14 & -32.4 & -29.7 & -26.1 & -35.9 & -38.3 \\
\hline Fluxes of diatoms multiplied by 2 & +6.9 & -4.7 & +6.7 & +5.8 & +4.8 & +6.2 & +8.4 \\
\hline Fluxes of diatoms divided by 2 & -3.1 & +2.3 & -3 & -2.1 & -2.3 & -1.6 & -4.2 \\
\hline Fluxes of dinoflagellates multiplied by 2 & $2-3.9$ & +27.9 & -3.4 & +0.5 & +0.2 & +1.6 & -0.5 \\
\hline Fluxes of dinoflagellates divided by 2 & +2.9 & -18.6 & +2.6 & +0.5 & 0 & +1.6 & +0.4 \\
\hline
\end{tabular}


Table 4. Total primary production, average phytoplankton concentration, yearly heat balance at air-sea interface, $\mathrm{N}$ fluxes from the river Seine and through the Straits of Dover during a 15 yr simulation study

\begin{tabular}{|c|c|c|c|c|c|}
\hline Year & $\begin{array}{l}\text { Total production } \\
\qquad\left(10^{3}{\left.\mathrm{t} \mathrm{yr}^{-1}\right)}^{-1}\right.\end{array}$ & $\begin{array}{l}\text { Phytoplanktonic concentration } \\
\qquad\left(\mu \mathrm{mol} \mathrm{l}^{-1} \mathrm{~N}\right)\end{array}$ & $\begin{array}{c}\text { N flux, Straits of Dover } \\
\left(10^{3}{\left.\mathrm{y} \mathrm{yr}^{-1}\right)}^{-1}\right.\end{array}$ & $\begin{array}{l}\text { Heat balance } \\
\left(\mathrm{kJ} \mathrm{cm}^{-2} \mathrm{yr}^{-1}\right)\end{array}$ & $\begin{array}{l}\text { N flux, Seine } \\
\left(10^{3}{\left.\mathrm{t} \mathrm{r}^{-1}\right)}^{-1}\right.\end{array}$ \\
\hline 1978 & 2639 & 1.167 & 373 & 7.64 & 72.5 \\
\hline 1979 & 2762 & 1.246 & 375 & 8.4 & 89.7 \\
\hline 1980 & 2616 & 1.153 & 387 & -15.74 & 83.3 \\
\hline 1981 & 2737 & 1.156 & 386 & 5.03 & 96.4 \\
\hline 1982 & 2751 & 1.093 & 380 & 4.34 & 96.5 \\
\hline 1983 & 2917 & 1.183 & 393 & -8.65 & 91.7 \\
\hline 1984 & 2919 & 1.196 & 370 & 2.52 & 86.4 \\
\hline 1985 & 2852 & 1.251 & 379 & -17.87 & 80 \\
\hline 1986 & 2536 & 1.126 & 389 & -3.12 & 83.3 \\
\hline 1987 & 2387 & 1.157 & 399 & -3.1 & 101.6 \\
\hline 1988 & 2925 & 1.232 & 395 & 24.61 & 112 \\
\hline 1989 & 2914 & 1.071 & 372 & 22.54 & 75.5 \\
\hline 1990 & 3160 & 1.23 & 363 & 16.15 & 61.8 \\
\hline 1991 & 2771 & 1.159 & 382 & 15.09 & 81.9 \\
\hline 1992 & 2658 & 1.09 & 375 & 6.24 & 79.9 \\
\hline
\end{tabular}

Results inferred from phytoplanktonic nitrogen concentrations roughly follow those of total production for fluctuations induced by rivers as well as by the Atlantic boundary. This underlines the overall soundness of our conclusions.

Influence of meteorological forcing: Results of some annual budgets deduced from simulations are shown in Table 4. Fig. 10 shows plotting of annual production (in terms of nitrogen) and nitrogen fluxes through the Straits of Dover, giving a more expressive overview of these 15 yr of simulation. Total primary production does not show any significant trend: its correlation coefficient over time is under 0.23 . Nor can we highlight any great differences between years, since $80 \%$ of the results fall within a range equal to 2 standard deviations around the average value, which amounts to $2.77 \times 10^{6} \mathrm{tyr}^{-1} \mathrm{~N}$. The same can be said for nitrogen fluxes through the Straits of Dover. No significant correlation was found between total primary production and nutrient fluxes from the river Seine $(r=-0.29)$ for inorganic nitrogen supply. This lowers the importance of this river in global primary production of the English Channel. A more significant correlation was found between total primary production and fluxes of nitrogen through the Straits of Dover $(\mathrm{r}=-0.52)$. This negative coefficient tends to indicate that high phytoplanktonic and especially diatom production lead to a greater accumulation of organic material in the sediment and, consequently lower horizontal pelagic fluxes of total nitrogen. Nitrogen supply from the river Seine and fluxes through the Straits of Dover are relatively well correlated ( $\mathrm{r}=0.77$ ), as a result of nutrient transport along the French coast of the eastern English Channel. Moreover a low coefficient of correlation $(r=0.4)$ was found between annual production and the yearly heat balance.

Within these global results are years which can be qualified as exceptional. Therefore, we chose to devote more accurate study to processes occuring during the years 1987, which could be regarded as a wet year, and 1990, during which weather was warm and dry. They are opposite, since 1987 showed a low level of production and 1990 a high one.

Phytoplankton simulations in boxes A, B, C, D and E are plotted for both these years in Fig. 11. The main differences are shown in the Bay of Seine (box D), where chlorophyll concentrations appear to be much higher in 1987 than in 1990. These differences are mainly related to nutrient fluxes from the river Seine (Table 4). Since the phytoplankton development, following the river supply, is in contrast to that of the English Channel's overall production, which was much lower in 1990 than in 1987, this result confirms the relatively limited influence of the Bay of Seine on the

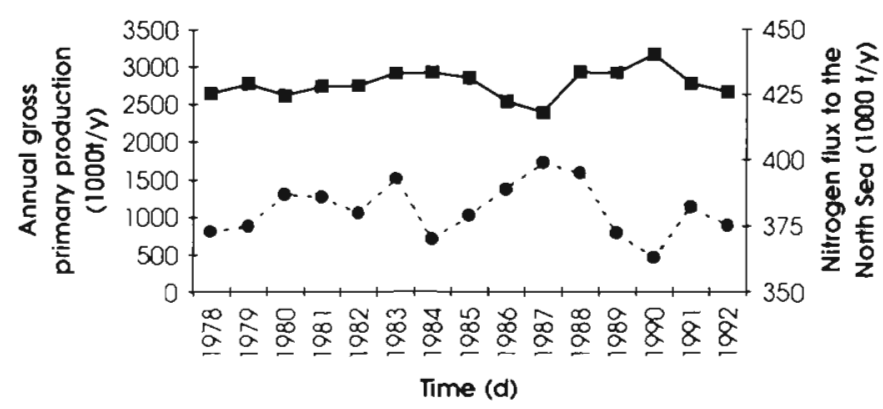

Fig 10. Annual gross primary production (solid line) and nitrogen fluxes (dotted line) through the Straits of Dover simulated between 1978 and 1992 


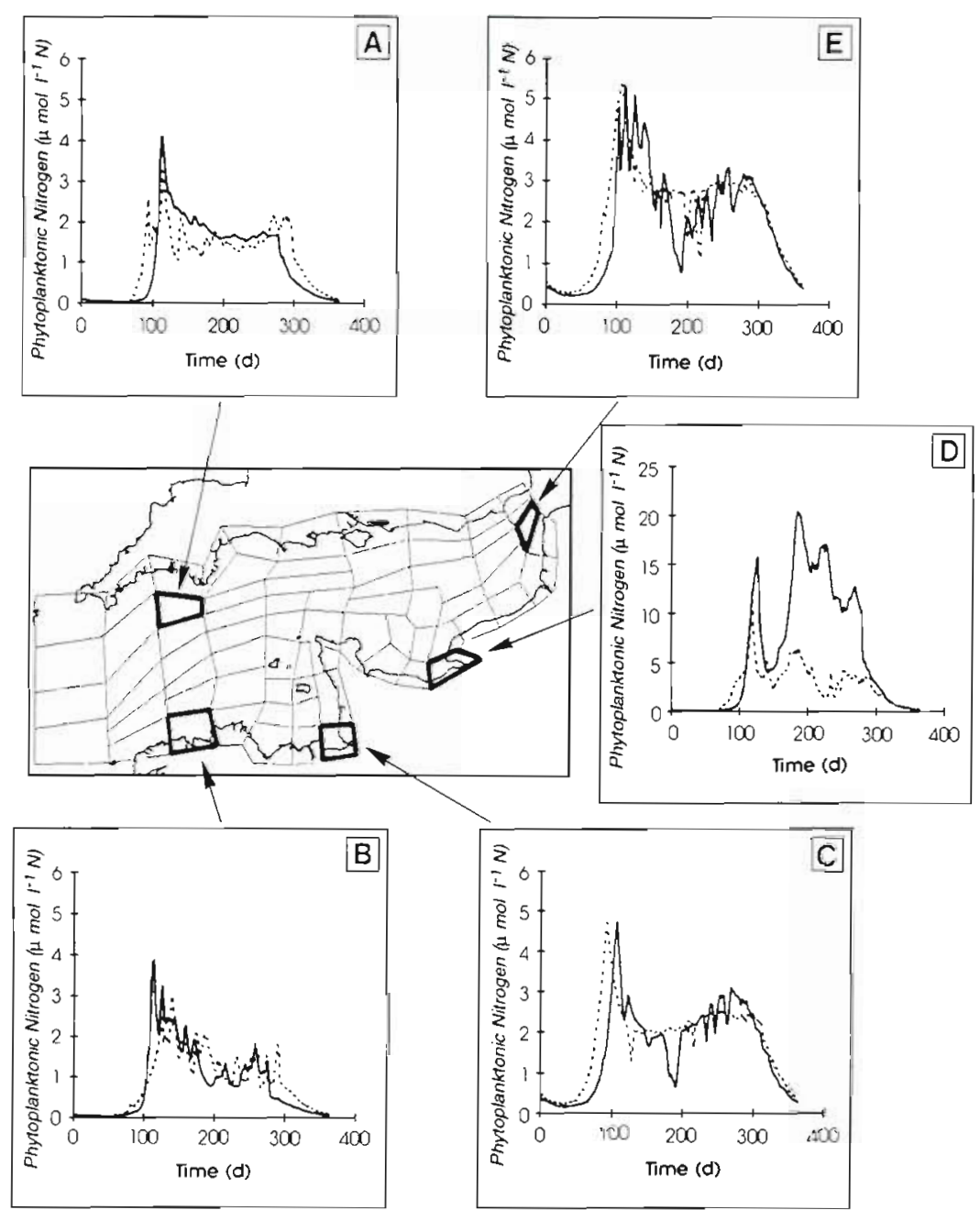

Fig. 11. Simulation of phytoplankton time course in boxes A to E for 1987 (solid line) and 1990 (dotted line)

global English Channel ecosystem. In the other boxes, the simulation did not lead to large differences between the 2 years. Nevertheless, phytoplanktonic development appears to be earlier in 1990 than in 1987, for boxes A, C and E.

To understand differences in primary production, results from the model for box A in the western English Channel (Fig. 12) were detailed. In 1990, the spring bloom was less intense but an episodic phytoplankton bloom occurred even though stratification was not well established. In contrast, phytoplankton development corresponded to an early stratification in 1987. Investigation of temperature and heat balance simulations clearly distinguishes the 2 years. Indeed, 1990 was a warm year but stratification was late, due to relatively bad weather in April. The delayed appearance of stratification was observed by Davies et al. (1992), who measured a bloom of Phaeocystis instead of diatoms. In contrast, although winter 1987 was particularly harsh, the thermocline was established early, thanks to good weather in April. In fact, heat fluxes in April were highly dependent on sea temperatures, because evaporation and convective fluxes were particularly high due to cold water in 1987. In this particular case, the harsher the winter weather, the earlier the stratification occurred in spring. These physical phenomena act on phytoplanktonic production, because stratified areas appear to be less productive than well-mixed ones, as was previously demonstrated. More-over, stratification promotes the development of dinoflagellates, which in turn lowers global primary production.

Similarly, no significant trend was shown for average phytoplanktonic nitrogen concentrations. Nor was there evidence of any dependence of this variable on either nutrient fluxes from the river Seine or the yearly heat balance. Differences observed between years 1985 and 1989 could also be explained by results in box $A$ (Fig. 13). In 1985, the simulation showed a relatively high level of phytoplanktonic $\mathrm{N}$ during summer, due to a rather weak and deep thermocline. In contrast, a stronger stratification in 1989 resulted in a thinner surface layer and hence, weaker phytoplanktonic nitrogen concentrations in summer.

It could be concluded from this $15 \mathrm{yr}$ simulation study that inputs from the river Seine are not the main factor acting on phytoplankton production of the English Channel, even if fluxes through the Straits of Dover are sensitive to them. Indeed, meteorological forcing mainly determines primary production. However, the yearly heat balance is not an appropriate index to assess the influence of the climate. The major role is played by the weather during winter and spring months, which defines the date of stratification.

As for phytoplanktonic nitrogen concentrations, in this case, what matters most is not the date of the stratification's appearance, but rather its stability and the depth of the upper layer.

\section{DISCUSSION AND CONCLUSION}

The companion paper highlighted the need to combine horizontal transport and vertical processes in the 

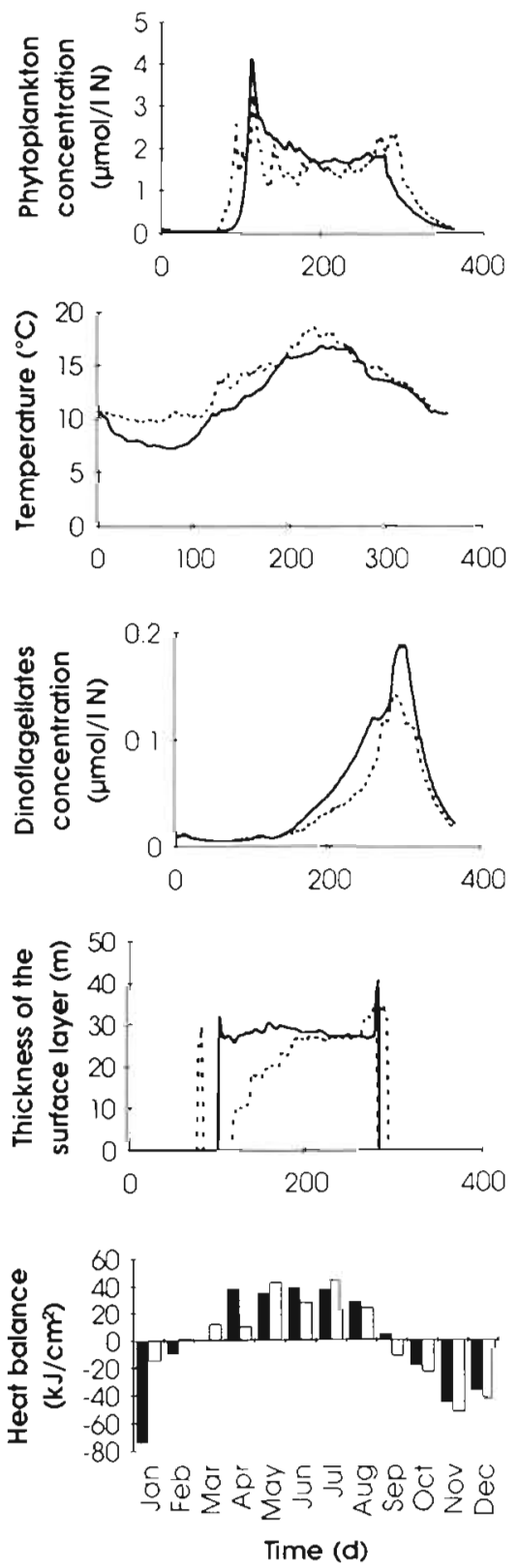

Fig. 12. Time course of various simulated variables in box $A$ for 1987 (solid line) and 1990 (dotted line). Also shown are heat balances due for the years 1987 (dark bars) and 1990 (light bars)

physical background of an ecological model applied to the English Channel. This paper has dealt more with the variability induced by a biological model and the consequences of this variability.

Firstly, the sensitivity of an ecological model may be defined by its different components: processes, parameters, boundary conditions and forcing variables. Each of these sensitivity analyses may be considered separately. With regard to model structure, we have underlined the strong influence of quota formulation,
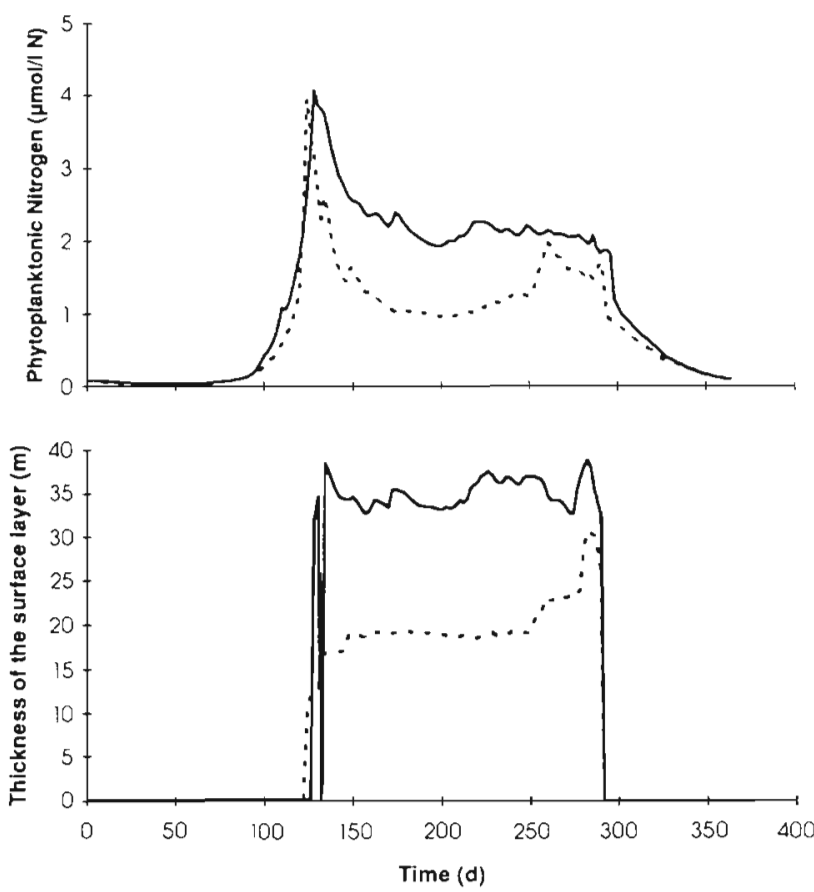

Fig. 13. Time course of phytoplanktonic nitrogen concentrations and thickness of the surface layer, in box A for the years 1985 (solid line) and 1989 (dotted line)

as previously noted by Haney \& Jackson (1996). This study has also demonstrated the role of phytoplankton in temperature modelling. Monte Carlo random simulations distinguished parameters to which the model is most sensitive. They emphasized the importance of competition phenomena between diatoms and dinoflagellates. Study of nutrient supply highlighted the dominant role of nitrogen inputs in the total primary production of the English Channel, especially those from the western oceanic boundary. Lastly, pluriannual simulations brought us to the conclusion of the ecosystem's relative stability, which is mainly controlled by meteorological changes.

The influence of biological processes on the thermal model has already been underlined by Sathyendranath et al. (1991). Using remotely sensed data on ocean colour, they showed that in the Arabian Sea, the monthly rate of heating attributable to phytoplankton could reach $4^{\circ} \mathrm{C}$. Similarly, Stramska \& Dickey (1993) estimated, at a high latitude site near Iceland, that the observed increase in phytoplankton abundance induced an increase in the sea surface temperature by about $0.2^{\circ} \mathrm{C}$, and a greater near-surface thermal stratification. These studies, like ours, indicate that the light extinction coefficient should be introduced as a term dependent on phytoplanktonic concentrations.

In fact, the English Channel as a whole does not show the characteristics of a coastal ecosystem. The 
global stability of phytoplanktonic production associated with high sensitivity to inputs from the Atlantic entrance illustrates the position of the English Channel as a link between the open sea and coastal zones eventually subject to eutrophication.

Nevertheless, calculation of fluxes through the Straits of Dover shows how important nutrient supply from the rivers is, especially in the eastern part of the English Channel. Much effort was devoted to estimating these fluxes (Bentley et al. 1993, Laane et al. 1993), since eutrophication problems appear on a much larger scale in the North Sea than in the English Channel (Cadée 1986, 1992, Joint \& Pomroy 1993). Intense blooms of Phaeocystis pouchettii have been recorded in the North Sea, related to increased nutrient concentrations (Lancelot et al. 1987, Rousseau \& Lancelot 1989). Therefore, although the English Channel plays a major role in the transfer of nutrients to the North Sea it is not facing massive eutrophication problems, except for a few specific areas.

Nutrient limitation study proved the need to focus on N, P and Si. These results are in good agreement with several studies already showing limitation by $\mathrm{P}$ (Pennock \& Sharp 1994) or Si (Dortch \& Whitledge 1992). However, nitrogen appears to be the main limiting element of phytoplanktonic production, whereas phosphorus is much less important. Silicon may be of particular interest in the future, because of increased anthropogenic nutrient supply, especially for nitrogen. As first mentioned by Aminot et al. (1986), concerning the Bay of Seine, and later by Smayda (1990), increased nitrogen and phosphorus inputs may lead to a disequilibrium between diatoms and dinoflagellates induced by a limitation by silicon. Egge \& Aksnes (1992) concluded after enclosure studies that silicate favoured diatom growth above a specific concentration threshold. In contrast, diatom predominance was replaced by that of flagellates under this threshold. Furthermore, high silicate concentrations prevented Phaeocystis sp. from becoming the predominant species. Similarly, Conley et al. (1993) reviewed the modification of silica's biogeochemical cycle with eutrophication. Indeed, increased diatom biomass generates a greater accumulation of biogenic silica in sediments, thus resulting in a decline in water column dissolved silica concentrations. These modifications lead to limitation of diatom growth by silicon and further changes in species composition.

Results show general good agreement between simulated and measured chl a patterns. The diatomdinoflagellate succession is reproduced because dinoflagellates only appear in summer (Fig. 6). Diatoms, however, form the major part of the spring bloom. This succession has been widely observed and could be attributed to the slower growth dynamics of dinoflagellates as well as nutrient depletion in the surface layer. Differential grazing pressure should also be taken into account. Dinoflagellates concentrations appear somewhat low but a 2-layer structure is far too imprecise to reproduce high concentrations of dinoflagellates on the pycnocline level in frontal and stratified areas (Holligan \& Harbour 1977, Bo Pedersen 1994). This could be achieved in an initial approximation by dividing the water column into 3 layers (Dianrong 1993). However, the most efficient approach would combine this biological model with a fine-scale grid physical model, having at least 10 levels on the vertical dimension, in order to obtain more accurate vertical turbulence profiles.

Further improvements of the biological model will require a realistic simulation of zooplankton development and grazing. This should also include the nanoflagellates which may play an important role in primary production, especially in stratified areas (Holligan et al. 1984)

Appendix 1. Equations and parameters from the reference model

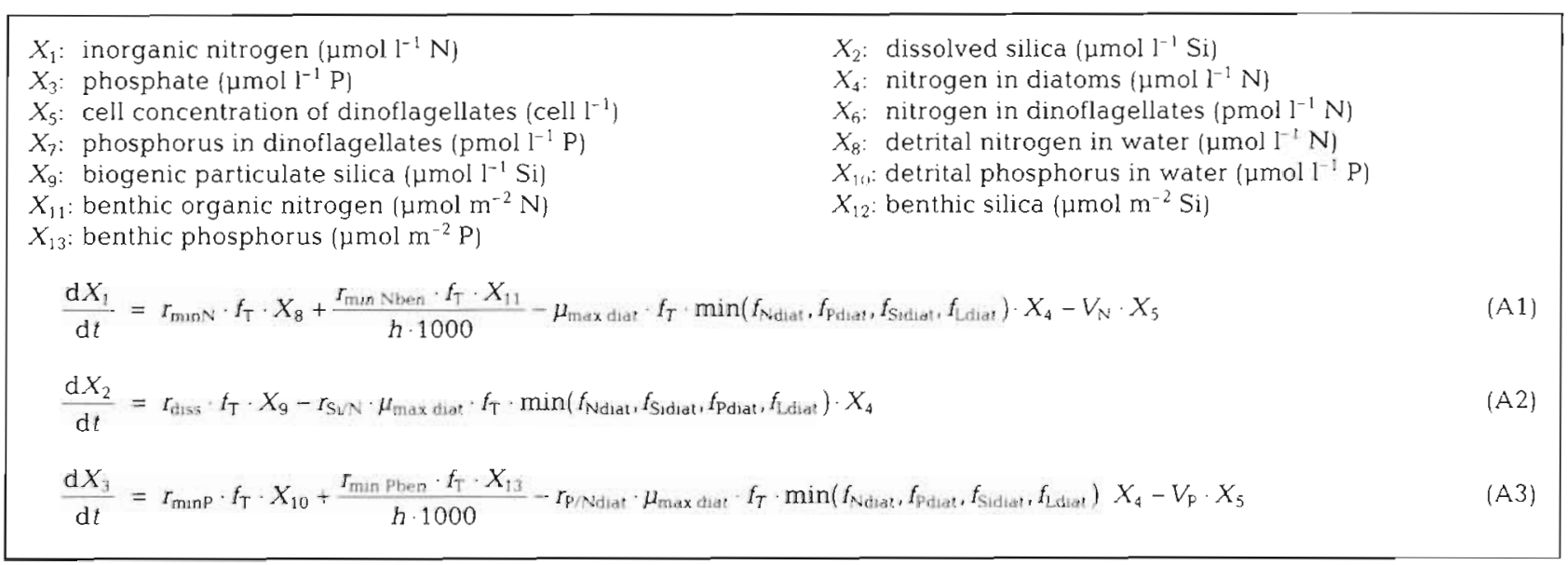




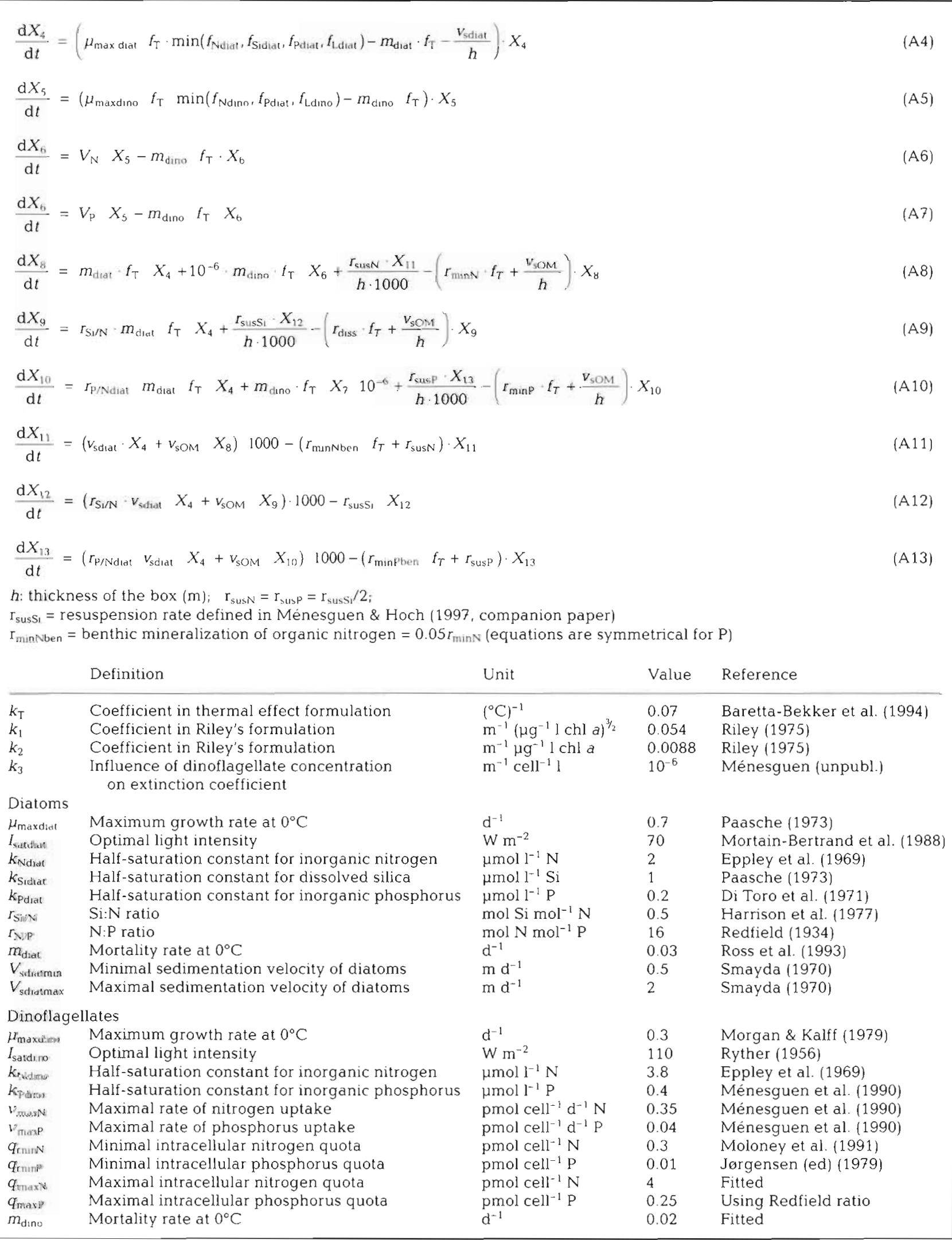


Appendix 1 (contınued)

\begin{tabular}{|c|c|c|c|c|}
\hline & Definition & Unit & Value & Reference \\
\hline \multicolumn{5}{|c|}{ Organic matter } \\
\hline$V_{\mathrm{SON}}$ & Sedimentation velocity of organic matter & $\mathrm{m} \mathrm{d} \mathrm{d}^{-1}$ & 1 & Bienfang (1980) \\
\hline$r_{\operatorname{rann}} \mathrm{N}$ & Mineralization rate of detrital nitrogen at $0^{\circ} \mathrm{C}$ & $d^{-1}$ & 0.04 & Vinogradov et al. (1973) \\
\hline$r_{\operatorname{minP}}$ & Mineralization rate of detrital phosphorus at $0^{\circ} \mathrm{C}$ & $d^{-1}$ & 0.1 & Fitted \\
\hline$r_{\text {dıss }}$ & Dissolution rate of partıculate silicon at $0^{\circ} \mathrm{C}$ & $d^{-1}$ & 0.05 & Kamatani (1971) \\
\hline
\end{tabular}

\section{LITERATURE CITED}

Agoumi A, Enderlé MJ, Gras RA (1983) Modélisation du régime thermique en Manche. Oceanol Acta 6:393-406

Aminot A, Kerouel R, Mauvais JL (1986) Les éléments nutritifs en Bale de Seine. La Baie de Seine (GRECO-MANCHE) Université de Caen, 24-26 avril 1985. IFREMER Actes Collog 4:289-296

Baretta-Bekker JG, Riemann B, Baretta JW, Koch Rasmussen E (1994) Testing the microhial loop concept by comparing mesocosm data with results from a dynamical simulation model. Mar Ecol Prog Ser 106:187-198

Bentley D, Lafite R, Morley NH, James R, Statham PJ, Guary JC (1993) Flux de nutriments entre la Manche et la Mer du Nord Situation actuelle et évolution depuis dix ans. Oceanol Acta 16:599-606

Bienfang PK (1980) Phytoplankton sinking rates in oligotrophic waters off Hawaii, USA. Mar Biol 61:69-77

Bo Pedersen F (1994) The oceanographic and biological tidal cycle succession in shallow sea fronts in shallow sea fronts in the North Sea and the English Channel. Estuar Coast Shelf Sci 38:249-269

Cadée GC (1986) Increased phytoplankton primary production in the Marsdiep area (western Dutch Wadden Sea) Neth J Sea Res 20:285-290

Cadée GC (1992) Trends in Marsdiep phytoplankton. Netherlands Institute for Sea Research, Publ Ser No. 20:143-149

Chapelle A, Lazure P, Ménesguen A (1994) Modelling eutrophication events in a coastal ecosystem. Sensitivity analysis. Estuar Coast Shelf Sci 39:529-548

Conley DJ, Schelske CL, Stoemer EF (1993) Modification of the biogeochemical cycle of silica with eutrophication. Mar Ecol Prog Ser 101:179-192

Davies AG. De Madariaga I, Bautista B, Fernandez E, Harbour DS, Serret P, Tranter PRG (1992) The ecology of a Phaeocystis bloom in the north-western English Channel in 1990. J Mar Biol Ass UK 72:691-708

Dianrong Y (1993) The three-layer model of the thermocline structure in the shallow seas. Acta Oceanol Sinica 12: $323-334$

Di Toro DM, O'Connor DJ, Thomann RV (1971) A dynamic model of phytoplankton populations in the SacramentoSan Joaquin Delta. Adv Chem Ser 106:131-180

Dortch Q, Whitledge TE (1992) Does nitrogen or silicon limit phytoplankton production in the Mississipi River plume and nearby regions? Cont Shelf Res 12:1293-1309

Droop MR (1973) Some thoughts on nutrient limitation in algae. J Phycol 9:264-272

Egge JK, Aksnes DL (1992) Silicate as regulating nutrient in phytoplankton competition. Mar Ecol Prog Ser 83:281-289

Eppley RW, Rogers JN, McCarthy JJ (1969) Half-saturation constants for uptake of nitrate and ammonium by marine phytoplankton. Limnol Oceanogr 14:912-920

Fasham MJR (1995) Variations in the seasonal cycle of bio- logical production in subarctic oceans: a model sensitivity analysis. Deep Sea Res 42:1111-1149

Fransz HG, Verhagen JHG (1985) Modelling research on the production cycle of phytoplankton in the southern bight of the North Sea in relation to riverborne nutrient loads. Neth J Sea Res 19:241-250

Goldman JC, Glibert PA (1983) Kinetics of inorganic nitrogen uptake by phytoplankton. In: Carpenter E, Capone DG (eds) Nitrogen in the marine environment. Academic Press, New York, p 487-512

Haney JD. Jackson GA (1996) Modelling phytoplankton growth rates. J Plankton Res 18:63-85

Harrison PJ, Conway HL, Holmes RW, Davis CO (1977) Marine diatoms grown in chemostats under silicate or ammonium limitation. III. Cellular chemical composition and morphology of Chaetoceros debilis, Skeletonema costatum, and Thalassiosira gravida. Mar Biol 43:19-31

Holligan PM, Harbour DS (1977) The vertical distribution and succession of phytoplankton in the western English Channel in 1975 and 1976. J Mar Biol Ass UK 57:1075-1093

Holligan PM, Harris RP, Newell RC, Harbour DS, Head RN, Linley EAS, Lucas MI, Tranter PRG, Weekley CM (1984) Vertical distribution and partitioning of organic carbon in mixed, frontal and stratified waters of the English Channel. Mar Ecol Prog Ser 14:111-127

Huntley ME (1982) Yellow water in La Jolla Bay, California, July 1980. II. Suppression of zooplankton grazing. J Exp Mar Biol Ecol 63:81-91

Jamart BM. Winter DF, Banse K (1979) Sensitivity analysis of a mathematical model of phytoplankton growth and nutrient distribution in the Pacific Ocean off the northwestern US coast. J Plankton Res 1:267-290

Joint I, Pomroy A (1993) Phytoplankton biomass and production in the southern North Sea. Mar Ecol Prog Ser 99: $169-182$

Jørgensen SE (ed) (1979) Handbook of environmental data and ecological parameters. Internatıonal Society for Ecological Modelling, Værløse

Kamatani A (1971) Physical and chemical characteristics of biogenous silica. Mar Biol 8:89-95

Laane RWPM, Groeneveld G, De Vries A, Van Bennekom J, Sydow S (1993) Nutrients (P, N, Si) in the Channel and the Dover Strait: seasonal and year-to-year variation and fluxes to the North Sea. Oceanol Acta 16:607-616

Lancelot C, Billen G, Sournia A, Welsse T, Colijn F, Veldhuis MJW, Davies A, Wassman P (1987) Phaeocystis blooms and nutrient enrichment in the continental coastal zones of the North Sea. Ambio 16:38-46

Le Corre P, L'Helguen S, Wafar M (1993) Nitrogen source for uptake by Gyrodinium cf aureolum in a tidal front. Limnol Oceanogr 38:446-451

Ménesguen A (1991) 'ELISE', an interactive software for modellıng complex aquatic ecosystems. In: Arcilla AS, Pastor M, Zienkiewicz OC, Schrefler BA (eds) Computer 
modelling in ocean engineering 91 . Balkema, Rotterdam, p $87-94$

Ménesguen A, Guillaud JF, Aminot A, Hoch T (1995) Modelling the eutrophication process in a river plume: the Seine case study (France). Ophelia 42:205-225

Ménesguen A, Hoch T (1997) Modelling the biogeochemical cycles of elements limiting the primary production in the Channel. I. Role of thermohaline stratification. Mar Ecol Prog Ser 146:173-188

Ménesguen A, Lassus P, De Crémoux F, Boutibonnes L (1990) Modelling Dinophysis blooms: a first approach. In: Granéli E (eds) Toxic marine phytoplankton. Elsevier Science Publishing, New York, p 195-200

Moloney CL, Field JG (1991) The size-based dynamics of plankton food webs. I. A simulation model of carbon and nitrogen flows. J Plankton Res 13:1003-1038

Moloney CL, Field JG, Lucas MI (1991) The size-based dynamics of plankton food webs. II. Simulation of three contrasting Southern Benguela food webs. J Plankton Res 13:1039-1092

Morgan KC, Kalff J (1979) Effect of light and temperature interactions on growth of Cryptomonas erosa (Cryptophyceae). J Phycol 15:127-134

Mortain-Bertrand A, Descolas-Gros C, Jupin H (1988) Growth, photosynthesis and carbon metabolism in the temperate marine diatom Skeletonema costatum adapted to low temperature and low photon-flux density. Mar Biol 100 $135-141$

Niller PP, Kraus EB (1977) One-dimensional models of the upper ocean. In: Kraus EB (ed) Modelling and prediction of the upper layers of the ocean. Proceedings of a NATO Advanced Study Institute. Pergamon Press, Oxford, $p$ 145-172

Paasche E (1973) Silicon and the ecology of marine plankton diatoms. II. Silicate-uptake kinetics in five diatom species. Mar Biol 19:262-269

Pennock JR, Sharp JH (1994) Temporal alternation between light- and nutrient-limitation of phytoplankton production in a coastal plain estuary. Mar Ecol Prog Ser 111:275-288

Pingree RD (1975) The advance and retreat of the thermocline on the continental shelf. J Mar Biol Ass UK 55:965-974

Pingree RD, Holligan PM, Mardell GT, Head RN (1976) The influence of physical stability on spring, summer and autumn phytoplankton blooms in the Celtic Sea. J Mar Biol Ass UK 56:845-873

Pingree RD, Maddock L, Butler EI (1977) The influence of biological activity and physical stability in determining the chemical distributions of inorganic phosphate, silicate and nitrate. J Mar Biol Ass UK 57:1065-1073

Platt T, Mann KH, Ulanowicz RE (1981) Mathematical models

This article was submitted to the editor in biological oceanography. The Unesco Press, Paris

Radach G, Moll A (1993) Estimation of the variability of production by simulating annual cycles of phytoplankton in the central North Sea. Prog Oceanogr 31:339-419

Redfield AC (1934) On the proportions of organic derivatives in sea water and their relation to the composition. James Johnstone Memorial Volume. Univ Liverpool, p 176-192

Riley GA (1975) Transparency-chlorophyll relations. Limnol Oceanogr 20:150-152

Ross AH, Gurney WSC, Heath MR, Hay SJ, Henderson EW (1993) A strategic simulation model of a fjord ecosystem Limnol Oceanogr 38:128-153

Rousseau V, Lancelot C (1989) Phaeocystis spring bloom in the continental coastal zone of the North Sea. In: Pichot G (ed) Progress in Belgian oceanographic research. Proceedings of the North Sea Symposium, Ghent, 14 February 1989. Prime Minister's Services, Science Policy Office Ministry of Public Health and Environment, Management Unit of the Mathematical Models of the North Sea and Scheldt Estuary (MUMM), Brussels, p 225-245

Ryther JH (1956) Photosynthesis in the ocean as a function of light intensity. Limnol Oceanogr 1:61-70

Salomon JC. Breton M (1993) An atlas of long term currents in the Channel. Oceanol Acta 16:439-448

Sathyendranath S, Gouvela AD, Shetye SR, Ravindran P, Platt $T$ (1991) Biological control of surface temperature in the Arabian Sea. Nature 349:54-56

Sharples J, Tett P (1994) Modelling the effect of physical variability on the midwater chlorophyll maximum. J Mar Res $52: 219-238$

Smayda TJ (1970) The suspension and sinking of phytoplankton in the sea. Oceanogr Mar Biol A Rev 8:353-414

Smayda TJ (1990) Novel and nuisance phytoplankton blooms in the sea: evidence for a global epidemic. In: Granéli E, Sundström B, Edler L, Anderson DM (eds) Toxic marine phytoplankton. Elsevier Science Publishing, New York, p 29-40

Stramska M, Dickey TD (1993) Phytoplankton bloom and the vertical thermal structure of the upper ocean. J Mar Res 51:819-842

Tett P, Edwards A, Jones KJ (1986) A model for the growth of shelf-sea phytoplankton in summer. Estuar Coast Shelf Sci 23:641-672

Tiwari JL, Hobbie JE (1976) Random differential equations as models of ecosystems: Monte Carlo simulation approach. Math Biosci 28:25-44

Vinogradov MY, Krapivin VF, Menshutkin VV, Fleyshman BS, Shushkina EA (1973) Mathematical model of the functions of the pelagial ecosystem in tropical regions (from the 50th voyage of the R/V VITYAZ'). Oceanology $13: 704-717$

Manuscript first received: July 20, 1995

Revised version accepted: October 10,1996 